\title{
Optimal renewable energy systems for industries in rural regions
}

\author{
Stephan Maier ${ }^{*}$ and Ariadni Gemenetzi
}

\begin{abstract}
Background: Energy systems for smart regions will require on the one hand a much higher share of renewable energy sources for heat and electricity and on the other hand a high standard integration of industry and utilities supplying households and businesses. As energy options become more diverse, integration of industry into the energy provision for settlements and vice versa become important from an economic and ecological point of view. A particular problem is the supply of bio-energy to large industrial complexes as this requires considerable efforts to manage resource provision as well as constructing smart systems to utilise available resources without posing direct competition to the supply of food and feed.

Methods: This paper will discuss the application of Process Network Synthesis (PNS) using the P-Graph method as a tool to generate optimal energy systems supplying industry with energy based on bio-resources in the context of a rural region and small urban centre. Application of these methods to a real life case study in an industrial city in rural context (Weiz in Austria) will be discussed from the viewpoint of general lessons to be learned from the design of complex energy systems linking different energy provision sources to supply industry and residential areas in a systemic way with energy.

Results: The synthesis resulted in a basic optimal solution containing the economically most feasible regional energy-technology network. Scenarios show differences in resource use and the creation of revenue. Anaerobic digestion, CHP and wood gasification appear for most of the scenarios.

Conclusions: The case study shows that a support of large consumers with sustainable regional energy systems can already be realised with current market prices. Heat demand outside industry critically influences the economic success of regional technology networks. Feed-in tariffs remain as a key factor for the creation of revenue. As regional parameters like resource availability, prices and locations where technologies could be situated change, the economic success also changes. Price limits and stable technologies can be identified.
\end{abstract}

Keywords: Renewable energy systems; Regional energy systems; Process synthesis; Renewable energy for industrial sites

\section{Background}

Regional energy systems of the future will have to be based on renewable sources to a much larger extent. Whereas there are interesting examples of an implementation of regional sustainable energy systems for relatively small and rural settings [1], integration of large consumers such as industrial plants as well as the supply for larger urban centres still remains a problem to be solved on a larger scale [2]. Utilisation of renewable resources as a base for the energy system will require to

\footnotetext{
* Correspondence: stephan.maier@tugraz.at

Institute for Particle and Process Engineering, Graz University of Technology,
} 8010 Graz/Gradec, Austria rethink the interaction between spatial planning, energy technologies and distribution grids [3] leading to the need of tailor-made solutions that take the individual context of the region into account. This includes the particular mix of available resources, the demand of energy in its various forms as well as the availability and capacity of distribution grids. For all these parameters, their spatial component and temporal characteristic have to be considered.

The development and implementation of smart energy systems on the regional level requires co-operation and co-ordination of a large number of economic, social, political and administrative actors. It is therefore less a

\section{Springer}


straightforward planning process than a deliberation process about future development. This deliberation has to be supported by appropriate methods that allow the optimisation of complex technology networks and resource logistics to provide solid ground for actor discourse.

In this research, an optimum technology network for a specific case study region shall be found. In the next step, scenarios will be made to identify price limits and technologies which have high grades of application stability. The objective of the study results in an adaptable optimum structure and scenarios which represent the existing technology network, available resources, prices, energy supply and demand situation of the region as well as possible new energy technologies. This model will then be used as a decision-making support tool for a specific region in Austria. It will set the basis for a future development of the city's energy system planning to raise optimum energy structures for the settlements and a specific industrial area. The research is part of a broader regional process. Because of structural changes in working behaviour, limits of resources and population growth, rural areas, urban spaces and industrial sides are drawing closer together. The region Weiz/Gleisdorf was chosen as a study area because the municipalities situated there work together to form a common energy region elaborating an energy concept involving industrial producers, energy suppliers and other regional and urban stakeholders. Results of the research are used for dialogue with regional stakeholders. The reason for the research discussion is finding the best regional solution, looking at resources, technologies and economics (optimal technology network) and analysing deviations when accounting for certain conditions, among other stakeholder interests. An integration of renewable technologies in energy supply networks has a promising potential to increase added municipal value [4].

\section{Problem definition}

The study area includes 19 municipalities in the region Weiz/Gleisdorf. This area qualified for an intensive investigation because it shows urban structures in a regional context, which means that there is a big potential of resources from rural areas and waste heat from an industrial side as well as demand from denser settlements in urban areas. The total area of the municipalities is 26,817 ha, with a population of 43,758 people. The biggest urban centre in this region is the city of Weiz with a surface area of 359 ha. The region in the South-East of Austria has a long industrial history and hosts a number of high-tech engineering and manufacturing sites.

The model requirements of the study were to find the optimal technology network as well as sites for energy provision installations that provide a large manufacturing plant with process heat and electricity, utilising regionally available bio-resources while generating the highest possible value added on a regional scale.

The design conditions of the study are not restricted to the provision of energy to the manufacturing plant but also allow to supply residential heat for nearby settlements in the urban centre of Weiz as well as provide bio-methane and electricity (from bio-resources) to the grid if this increases the overall economic performance of the system.

The Process Network Synthesis (PNS) had to render consistent and comparable optimal solutions for this task based on different scenarios. These scenarios take into account: the variability of cost and price options, availability of resources, and the availability of locations for construction area as well as market developments (demand for heat and electricity).

The results from the calculations form the base for a broad stakeholder discourse currently going on in the region.

\section{Energy demand and spatial context}

South of the city of Weiz, the energy demand of ELIN motor factory shall be supplied by the energy system developed here. Its current energy demand accounts for 3,421 $\mathrm{MWh}_{\mathrm{el}}$ electricity per year and 271,112 $\mathrm{Nm}^{3}$ natural gas per year, partly for supply of high temperature process heat. The natural gas is burnt by an existing gasfired boiler and the heat from it is currently covering their heat demand.

In consultations with the municipalities involved, three locations (L1 Thannhausen North, L2 Thannhausen South and L3 Mortantsch in Figure 1) were identified for possible constructions of energy provision centres including anaerobic digestion and/or biomass gasification plants, along with auxiliary installations (e.g. CHP plants, biogas upgrading plants, etc.). At the site of the manufacturing plant, a new CHP plant is also optional.

\section{Methods}

A number of recent publications have tackled regionally adapted smart energy systems. The evaluation of available renewable energy sources, calculated energy potential, land use of available land for energy or food and appropriate energy supply chains help to locate energy targets implementing a cost and emission saving regional resource management [5]. An observation of heat integration and heat storage over time, e.g. solar thermal energy supply, shows that energy use can be reduced significantly [6]. One method that has in particular proven its worth in such processes is Process Network Synthesis (PNS) [7]. This method has been developed in the framework of process technology [8]. This method uses a bipartite graph method ( $\mathrm{P}$-graph method) to describe process networks and employs combinatorial rules to 


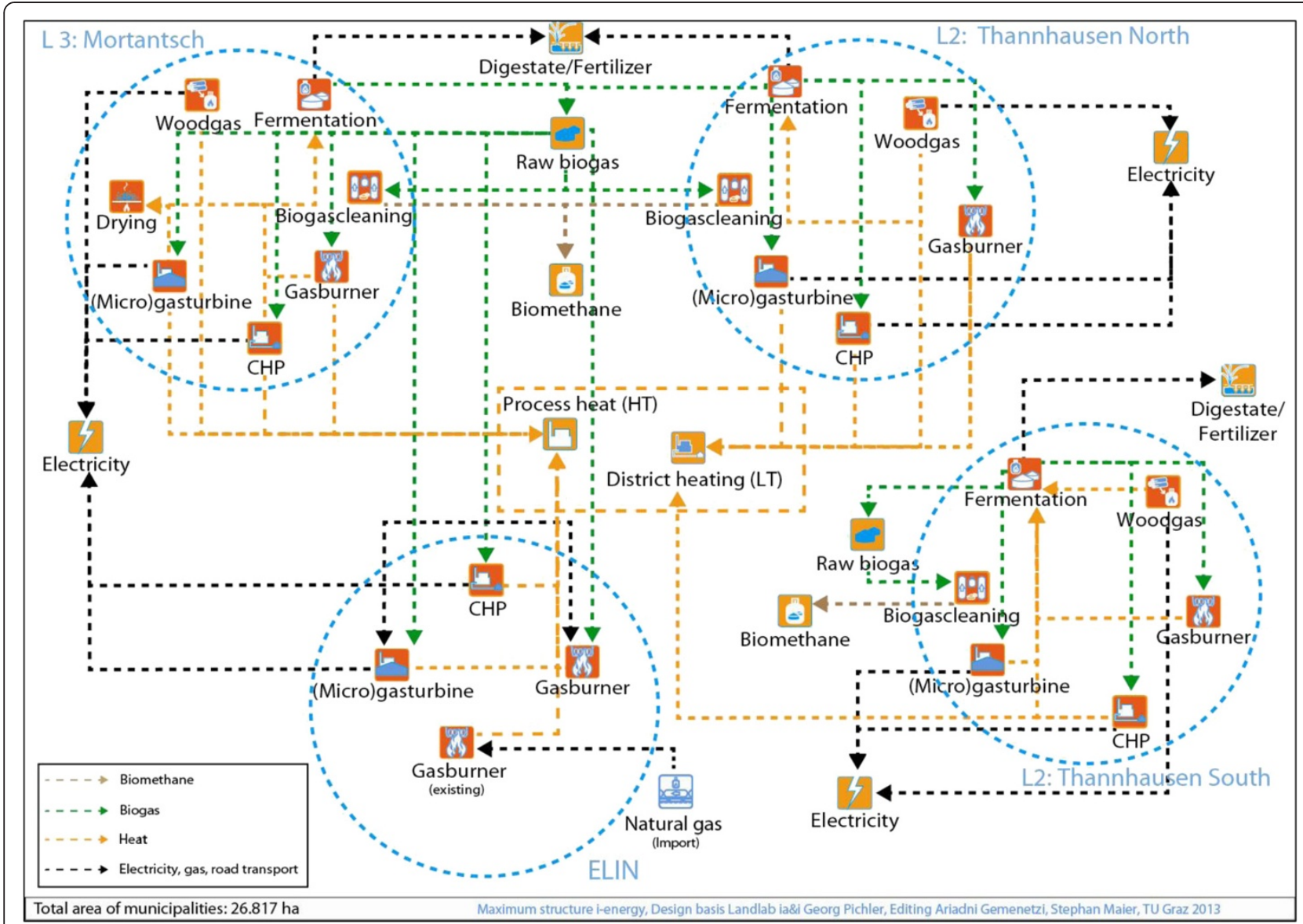

Figure 1 Maximum structure for the energy system.

find all feasible network solutions (the maximum structure) using all possible raw materials, intermediate products and products as well as all relevant technologies processing these materials. The maximum structure then is the starting point for a rigorous evaluation of all feasible process networks linking raw materials to the desired products, using a branch-and-bound optimisation routine. The software employing this method is freely accessible from www.p-graph.com/pnsstudio, TU Graz [9].

The method has successfully been applied to regional resource utilisation problems [10]. A special software tool to provide a preliminary overview of the potential of a certain region for smart energy systems based on renewable resources using the PNS method (RegiOpt) was recently developed and is available on the internet (regiopt.tugraz.at, TU Graz [11]).

In this study, an in-depth planning for the integration of a large industrial plant into a regional energy system using the PNS method was carried out. The goal of this work was to provide decision makers in a region with the rational foundation for their discourse to develop and implement a smart energy system. In a precursor project to the current work, a participatory discourse with citizens and actors was conducted to establish a shared vision of the future of the region. A result of this process was that the region wants to retain its industrial prowess that is particularly strong regarding energy and automotive industry but, at the same time, wants to switch its base for energy provision entirely to renewable resources within the next 20 to 30 years. The task of the current work was therefore to provide the base for this transition, with a focus on supplying industrial sites as well as the urban centres with energy from renewable resources provided by the region.

\section{Technology network synthesis model}

For the synthesis, a maximum technology and material flow structure was generated, including all technology options as well as all possible grid structures. A thorough analysis of all available bio-resources was carried out, including waste flows from agriculture, society and other industrial sectors, in particular the regionally important food industry. The data collected include all cost of biomass transport between their respective location of generation and the four locations selected for possible implementation of energy technologies (the three energy provision sites and 
the industrial plant). High-temperature (HT) pipes for industrial heat, low-temperature (LT) pipes for district heat and gas pipes for the transport of biogas were used in the maximum structure as well as gas cleaning and feed gases into gas-and-electricity-grid options. In terms of possible technologies in the energy system, the maximum structure contains wood gasification plants, (micro)gas turbines, CHPs, gas burners, digesters, gas cleaning/upgrading, heat distribution pipes, gas distribution pipes as well as gas compressors.

Approximately 20,462 ha of the total area of the municipalities under agricultural management and forestry may be used for energy purposes. The area currently used for livestock breeding (a major agricultural sector in the region) is excluded from consideration here although competition with the food sector must be avoided according to the consensus of the involved actors. For energy production, wood from forests, grass from permanent meadows, grass/short rotation/miscanthus on agricultural fields and residues from municipal bio-waste are included in the maximum structure. Possible end products are electricity, industrial heat, district heat, upgraded biogas and digestate (digestion residue), which can be used as fertiliser. The time period for the synthesis was chosen as 1 year. Supplementary requirements of the specific local structural situations were taken into account. All cost and price assumptions for resources, transport and equipment were checked with the actors involved in the regional energy system. Input and output flows used in the PNS are rated at market prices. Input flows (materials) are accounted for at prices that accrue if the resources are purchased on the market. Output flows (products) have local selling prices to consumers. Subsidised 'feed-in tariffs' for electricity and gas are considered and may either be limited or excluded in some scenarios. Table 1 offers an overview on the economic assumptions used in the optimisation.

The data summarised in Table 1 were entered into the PNS software, segmented into raw materials (fossil and renewable resources), intermediates (e.g. raw material before use for energy production), products (e.g. electricity) and operating units (conversion technologies and piping). A detailed description of the technology network can

Table 1 Resources, products and technologies of the maximum technology network

\begin{tabular}{ll}
\hline Raw materials (input) & $\begin{array}{l}\text { Natural gas, diesel, electricity, grass, miscanthus, } \\
\text { short rotation, woodchips, municipal waste, manure }\end{array}$ \\
Products (output) & $\begin{array}{l}\text { Domestic heat, industrial heat, raw biogas, } \\
\text { upgraded biogas, biomass, digestate, remuneration } \\
\text { tariff municipal waste }\end{array}$ \\
Technologies & $\begin{array}{l}\text { Digester, CHP, gas-fired boilers, microgas turbines } \\
\text { and small turbines, wood gasifier, PSA, raw biogas } \\
\text { pipeline, biogas feed-in station, district heating } \\
\text { pipelines, dryer, filtering and shredding, chopper }\end{array}$ \\
\hline
\end{tabular}

be found in the Appendix. Figure 1 depicts the scheme of the resulting maximum structure.

The industrial site (ELIN motors) may be connected to all three possible locations for electricity, gas and heat production out of the regions' renewable resources. The produced raw biogas (from digesters or biomass gasifiers) can either be burned on site, transported to other locations including ELIN motor factory (via special biogas lines) or the biogas can be upgraded and fed into the next possible feed-in point of the gas distribution grid. Based on the maximum structure, the PNS serves to find value chains with the optimal value added.

\section{Results and discussion}

The synthesis of the optimal technology network was carried out with PNS studio 3.0.4, 2011, (accessible via www.p-graph.com/pnsstudio) using the maximum structure described above. The optimal energy system supplies energy to the industrial site in the form of biogas, electricity and heat. Moreover, it allows for district heat provision to the municipalities of Weiz, St. Ruprecht, Thannhausen, Krottendorf and Unterfladnitz. A gross benefit of $274,875 € /$ year can be achieved, calculated as if the technology network would be operated by one company, all consumers paying market prices for energy services, all suppliers being paid market prices for their resources and capital cost (active life span for equipment is 10 years) as well as operating cost for installations factored in. The gross profit provides a first indication of the viability of an energy system based on renewable resources, before further limitations are taken into account. Figure 2 shows the generated optimum structure.

Table 2 presents the raw material consumption as well as the energy output of the optimal technology network. Table 2 also indicates how much of the available agricultural land would be used by the technologies in the optimal network.

From the results of the (unrestricted) optimisation, it becomes clear that in principle, the provision of electricity for the industrial plant is viable, using current feed-in tariffs to calculate the revenue. Provision of high-temperature industrial heat based on renewable resources is still not economically viable given the competition with natural gas. The optimal network operates all possible sites, using digesters and CHP based on biogas. Bio-waste from the region shall be fully utilised; the green biomass potential from grasslands and fields (used as intensive grass production fields) is used to $54.6 \%$ and $40 \%$, respectively. Wood gasification is only installed in one site, using just $1.7 \%$ of the available forest resource. The manure potential is utilised to $40 \%$.

The unrestricted optimum structure is a first and important baseline for the further planning process. It is however usually impossible to implement, due to conflicting actors 


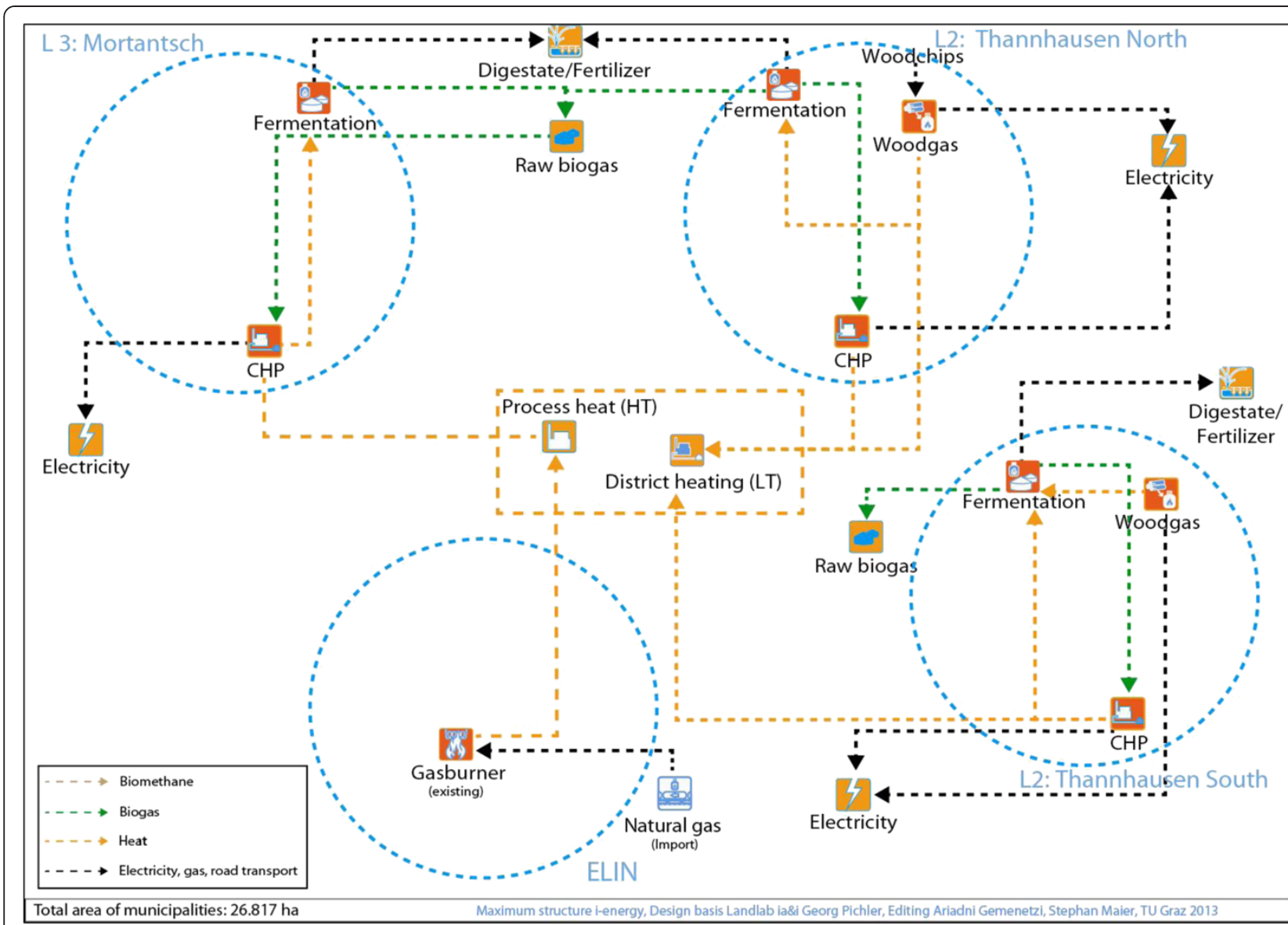

Figure 2 Optimal technology network.

Table 2 Resource and product output for the optimal technology network

\begin{tabular}{|c|c|c|c|}
\hline & \multicolumn{3}{|c|}{ Output } \\
\hline & Consumption & Weight & $\%$ Available \\
\hline \multicolumn{4}{|l|}{ Resource $(r m=15 \%)$} \\
\hline Woodchips & 275 ha & $2,145 \mathrm{t}$ & 1.7 \\
\hline Grass from meadows & 2,290 ha & $12,959 \mathrm{t}$ & 54.6 \\
\hline Grass from agricultural land & 113 ha & $436 t$ & 40.2 \\
\hline Manure (w = 28.7\%) & $\begin{array}{c}\text { 3,340 livestock } \\
\text { units }\end{array}$ & $43,742 t$ & 40.5 \\
\hline Bio-waste ( $w=27.8 \%)$ & $\begin{array}{c}1,103 \mathrm{t} \text { of } \\
\text { municipal waste }\end{array}$ & $525 \mathrm{t}$ & 100 \\
\hline \multicolumn{4}{|l|}{ Product } \\
\hline Heat & \multicolumn{2}{|c|}{$7,156 \mathrm{MWh}_{\mathrm{th}} /$ year } & \\
\hline Electricity & \multicolumn{2}{|c|}{ 9,572 $\mathrm{MWh}_{\mathrm{el}} /$ year } & \\
\hline Digested residue & \multicolumn{2}{|l|}{54,386 t/year } & \\
\hline
\end{tabular}

$\mathrm{rm}$, residual moisture; $\mathrm{w}$, water content. interests. In order to generate a 'playing field' for the actor discourse within the region, 21 scenarios with different restrictions were generated, taking possible restrictions in markets as well as sites into account. These scenarios that were generated based on input from various actors in the region, form the framework within which the stakeholder discourse will search for a system that optimises fulfillment of stakeholder expectations. Table 3 provides an overview of the different scenario groups. Table 3 summarises the results in terms of gross profit, energy output and resources' use (as a fraction of available resources) for each scenario group.

\section{Interpretation of results of the scenarios}

Since the city of Weiz already has an existing woodbased district heating system, the additional district heat that is generated via the CHPs at the three locations may overload the local market. With this in mind, four scenarios (scenario group A) were created with different demands for the heat market, from the provision of heat for a smaller settlement to unlimited heat demand. Revenues differ widely, from 206,015 €/year to 
Table 3 Scenario description

\begin{tabular}{|c|c|c|c|c|}
\hline Scenario group and number & $\begin{array}{l}\text { Revenue } \\
€ / \text { year }\end{array}$ & Energy produced & $\%$ of available resources used & Characteristics \\
\hline \multirow[t]{5}{*}{ A1 to $\mathrm{A} 4: 0 \%$ to $100 \% \mathrm{DH}$} & \multirow{5}{*}{$\begin{array}{c}206,015 \text { to } \\
341,690\end{array}$} & 7,518 to $15,169 \mathrm{MWh}_{\text {th }}$ & 0 to $2.8 \%$ wood forest & \multirow{5}{*}{$\begin{array}{l}\mathrm{DH} \text { is possible only to the municipality } \\
\text { of St. Ruprecht up to unlimited DH. }\end{array}$} \\
\hline & & 8,505 to $12,880 \mathrm{MWh}_{\mathrm{el}}$ & $72.1 \%$ to $79.5 \%$ grass meadow & \\
\hline & & & $62.3 \%$ to $74.4 \%$ grass ${ }_{\text {agr.land }}$ & \\
\hline & & & $37.6 \%$ to $44.1 \%$ manure & \\
\hline & & & 100\% biowaste & \\
\hline \multirow[t]{5}{*}{ B1: Location 3 exclusion } & \multirow[t]{5}{*}{241,695} & $9,596 \mathrm{MWh}_{\text {th }}$ & $1.7 \%$ wood forest & \multirow{5}{*}{$\begin{array}{l}\text { Mortantsch was not considered in the } \\
\text { PNS structure. }\end{array}$} \\
\hline & & $7,573 \mathrm{MWh}_{\mathrm{el}}$ & $42.5 \%$ grass meadow & \\
\hline & & & $31.7 \%$ grass agr.land & \\
\hline & & & $23.4 \%$ manure & \\
\hline & & & $100 \%$ biowaste & \\
\hline \multirow[t]{5}{*}{ C1: Higher natural gas price } & \multirow[t]{5}{*}{272,010} & $11,525 \mathrm{MWh}_{\mathrm{th}}$ & $2.1 \%$ wood forest & \multirow{5}{*}{$\begin{array}{l}\text { Assessment of the price results in no } \\
\text { natural gas usage from ELIN. }\end{array}$} \\
\hline & & $11,542 \mathrm{MWh}_{\mathrm{el}}$ & $72.5 \%$ grass meadow & \\
\hline & & & $62.3 \%$ grass $s_{a g r . l a n d}$ & \\
\hline & & & $43.2 \%$ manure & \\
\hline & & & $100 \%$ biowaste & \\
\hline \multirow{5}{*}{$\begin{array}{l}\text { C2: Higher biogas } \\
\text { feed-in tariff }\end{array}$} & \multirow[t]{5}{*}{290,130} & $9,658 \mathrm{MWh}_{\mathrm{th}}$ & $2.8 \%$ wood forest & \multirow{5}{*}{$\begin{array}{l}\text { Assessment of the biogas feed-in tariff } \\
\text { that results in biogas upgrading } \rightarrow \text { feed-in } \\
\text { tariff to the grid. }\end{array}$} \\
\hline & & $8,011 \mathrm{MWh}_{\mathrm{el}}$ & $93.4 \%$ grass $m$ meadow & \\
\hline & & 16,164 MWh & $87.9 \%$ grass agr.land & \\
\hline & & (upgraded DIogas) & $45.4 \%$ manure & \\
\hline & & & $100 \%$ biowaste & \\
\hline \multirow[t]{5}{*}{ D1: No tariffs } & \multirow[t]{5}{*}{251,634} & $12,893 \mathrm{MWh}_{\mathrm{th}}$ & $4.2 \%$ wood forest & \multirow{5}{*}{$\begin{array}{l}\text { Biogas feed-in and electricity tariffs } \\
\text { obtain regular market prices. }\end{array}$} \\
\hline & & $11,030 \mathrm{MWh}_{\mathrm{el}}$ & $41.4 \%$ grass meadow & \\
\hline & & & $31.4 \%$ grass agr.land & \\
\hline & & & $10.5 \%$ manure & \\
\hline & & & $100 \%$ biowaste & \\
\hline \multirow{5}{*}{$\begin{array}{l}\text { D2: No special electricity } \\
\text { feed-in tariffs }\end{array}$} & \multirow[t]{5}{*}{267,126} & $9,769 \mathrm{MWh}_{\text {th }}$ & $4.2 \%$ wood forest & \multirow{5}{*}{$\begin{array}{l}\text { Electricity tariffs obtain the regular } \\
\text { electricity market price. }\end{array}$} \\
\hline & & $6,000 \mathrm{MWh}_{\mathrm{el}}$ & $60.3 \%$ grass $_{\text {meadow }}$ & \\
\hline & & 16,164 MW & $39.5 \%$ grass agr.land & \\
\hline & & (upgraded blogas) & $22.2 \%$ manure & \\
\hline & & & $100 \%$ biowaste & \\
\hline \multirow{5}{*}{$\begin{array}{l}\text { D3 to D4: } 60 \% \text { to } 100 \% \\
\text { electricity tariffs reduction }\end{array}$} & \multirow{5}{*}{$\begin{array}{l}16,780 \text { to } \\
30,208\end{array}$} & 2,156 to $3,649 \mathrm{MWh}_{\mathrm{th}}$ & $0 \%$ to $0.8 \%$ wood forest & \multirow{5}{*}{$\begin{array}{l}\text { Electricity tariffs are reduced by } \\
60 \% \text { to } 100 \% \text {. }\end{array}$} \\
\hline & & $1,200 \mathrm{MWh}_{\mathrm{el}}$ & $59.6 \%$ to $60.1 \%$ grass meadow & \\
\hline & & 14,617 to $16,164 \mathrm{MW}$ & $44.1 \%$ grass agr.land & \\
\hline & & & $21.9 \%$ to $22.2 \%$ manure & \\
\hline & & & $100 \%$ biowaste & \\
\hline \multirow[t]{6}{*}{ E1: No forest area available } & \multirow[t]{6}{*}{251,893} & $11,360 \mathrm{MWh}_{\mathrm{th}}$ & $0 \%$ wood forest & \multirow{6}{*}{$\begin{array}{l}\text { Wood chips are not available, thus } \\
\text { short rotation and/or miscanthus have } \\
\text { to be used as feedstock in the gasifier. }\end{array}$} \\
\hline & & $10,376 \mathrm{MWh}_{\mathrm{el}}$ & $80.7 \%$ grass meadow & \\
\hline & & & $53.7 \%$ grass agr.land & \\
\hline & & & $22.1 \%$ miscanthus & \\
\hline & & & $44.9 \%$ manure & \\
\hline & & & $100 \%$ biowaste & \\
\hline \multirow{2}{*}{$\begin{array}{l}\text { E2: No municipal } \\
\text { waste availability }\end{array}$} & 158,212 & $11,030 \mathrm{MWh}_{\text {th }}$ & $1.7 \%$ wood forest & No municipal waste, i.e. Digester types \\
\hline & & 9,530 MWhel & $61.3 \%$ grass meadow & \\
\hline
\end{tabular}




\begin{tabular}{|c|c|c|c|c|}
\hline \multirow{7}{*}{$\begin{array}{l}\text { E3 to E5: } 0 \% \text { to } 50 \% \\
\text { grass availability }\end{array}$} & & & $40.2 \%$ grass agr.land & \multirow{8}{*}{$\begin{array}{l}\text { No grass, i.e. only digesters A, fuelled } \\
\text { with manure available. Up to: Less than } \\
\text { the meadow grass amount used in the } \\
\text { initial optimum structure, available. }\end{array}$} \\
\hline & & & $40.5 \%$ manure & \\
\hline & & & $0 \%$ biowaste & \\
\hline & \multirow{5}{*}{$\begin{array}{l}35,087 \text { to } \\
244,999\end{array}$} & \multirow{5}{*}{$\begin{array}{c}7,505 \text { to } 10,181 \mathrm{MWh}_{\text {th }} \\
8,455 \mathrm{MWh}_{\mathrm{el}}\end{array}$} & $2 \%$ to $2.6 \%$ wood forest & \\
\hline & & & $0 \%$ to $39.6 \%$ grass meadow & \\
\hline & & & $0 \%$ to $37.2 \%$ grass ${ }_{\text {agr.land }}$ & \\
\hline & & & $24.9 \%$ to $40.5 \%$ manure & \\
\hline & & & $0 \%$ to $100 \%$ biowaste & \\
\hline \multirow{5}{*}{$\begin{array}{l}\text { E6 to } \mathrm{E} 7: 10 \% \text { to } 50 \% \\
\text { manure availability }\end{array}$} & \multirow{5}{*}{$\begin{array}{l}202,146 \text { to } \\
257,789\end{array}$} & 9,837 to $11,971 \mathrm{MWh}_{\text {th }}$ & $1.7 \%$ to $1.9 \%$ wood forest & \multirow{5}{*}{$\begin{array}{l}\text { It limits the possibility of digester } \\
\text { type } A \text {. }\end{array}$} \\
\hline & & 7,154 to $9,598 \mathrm{MWh}_{\mathrm{el}}$ & $39.2 \%$ to $67.6 \%$ grass $m$ meadow & \\
\hline & & & $33.5 \%$ to $40.2 \%$ grass ${ }_{\text {agr.land }}$ & \\
\hline & & & $10.0 \%$ to $16.0 \%$ manure & \\
\hline & & & $100 \%$ biowaste & \\
\hline \multirow{5}{*}{$\begin{array}{l}\text { E8: } 33 \% \text { grass and } 50 \% \\
\text { manure availability }\end{array}$} & \multirow[t]{5}{*}{195,914} & $8,874 \mathrm{MWh}_{\mathrm{th}}$ & $1.9 \%$ wood forest & \multirow[t]{5}{*}{ Limits digesters' possibility. } \\
\hline & & 6,407 $\mathrm{MWh}_{\mathrm{el}}$ & $28.8 \%$ grass $m e a d o w$ & \\
\hline & & & $27.6 \%$ grass agr.land & \\
\hline & & & $15.3 \%$ manure & \\
\hline & & & $100 \%$ biowaste & \\
\hline \multirow{5}{*}{$\begin{array}{l}\text { F1: No selling price } \\
\text { for digestate }\end{array}$} & \multirow[t]{5}{*}{151,723} & $9,051 \mathrm{MWh}_{\mathrm{th}}$ & $1.8 \%$ wood forest & \multirow[t]{5}{*}{ A revenue source is excluded. } \\
\hline & & 6,527 $\mathrm{MWh}_{\mathrm{el}}$ & $35.7 \%$ grass meadow & \\
\hline & & & $24.9 \%$ grass agr.land & \\
\hline & & & $9.2 \%$ manure & \\
\hline & & & $98.7 \%$ biowaste & \\
\hline \multirow{5}{*}{$\begin{array}{l}\text { F2: } 8 € \text { selling price } \\
\text { for digestate }\end{array}$} & \multirow[t]{5}{*}{627,657} & $12,819 \mathrm{MWh}_{\text {th }}$ & $2.3 \%$ wood forest & \multirow[t]{5}{*}{ A revenue source is enhanced. } \\
\hline & & $14,070 \mathrm{MWh}_{\mathrm{el}}$ & $81.5 \%$ grass $m$ meadow & \\
\hline & & & $75.8 \%$ grass $_{\text {agr.land }}$ & \\
\hline & & & $85.5 \%$ manure & \\
\hline & & & $100 \%$ biowaste & \\
\hline
\end{tabular}

$\mathrm{DH}$, district heat.

$341,690 € /$ year (or $75 \%$ to $125 \%$ of the optimal revenue). This result highlights the importance of the heat market for the economic success of the overall energy system. In terms of resources, higher heat demand would require a (modest) recourse to forest resources.

One of the sites for energy centres, namely Mortantsch, is geographically less advantageous situated than the others. Therefore, one scenario (scenario group B) took up this issue by taking out this location from the maximum structure. The result shows that the objective to provide the ELIN Motorenwerk with electricity can still be met; the revenue however will decrease to approximately $88 \%$ of the optimal revenue.

The current optimal technology network solution does not supply the industrial heat for the ELIN Motorenwerk as this is not competitive to the current cost for supplying high temperature heat via a gas burner using natural gas at a price of $42.5 € / \mathrm{MWh}$. Scenario group $\mathrm{C}$ therefore investigated how the gas price as well as the gas feed-in tariff will impact the optimal technology network. Already at a natural gas price of $44 € / \mathrm{MWh}$ will change this situation fundamentally. If this gas price is assumed, the existing gas burner will not be part of the technology network and will be replaced by a biogas pipeline from the site Thannhausen South to the industrial plant, a biogas CHP and a small gas turbine at the ELIN Motorenwerk. This will reduce the overall revenue just by $1 \%$ in comparison with the optimal technology network, which still uses natural gas for industrial heat. Resource utilisation will also increase in this scenario, using $72 \%$ and $62 \%$ of the grassland and available fields, $43 \%$ of manure and $2 \%$ of the forest resources. This is a particularly interesting scenario as it shows how close to economic competitiveness a fully renewable energy provision for the industrial complex is already today! 
Increasing the feed-in tariff for upgraded biogas from currently $70 € / \mathrm{MWh}$ by less than $10 \%$ to $76 € / \mathrm{MWh}$ will have a profound change to the technology structure as at that price, biogas upgrading will become part of the optimal technology network. This will result in an evenfurther increase of resource utilisation (93\% and $88 \%$ of grass land and fields, respectively) and an increase in revenue to $105 \%$ of the optimal technology network calculated with current prices.

The optimal network was based on the assumption that electricity can be sold at current feed-in tariffs for biogas CHP. Scenario group D investigated the impact of changes in these feed-in tariffs. A reduction of more than $50 \%$ in feed-in tariffs will eliminate the electricity production via CHP at the three sites completely. Biogas produced will then be upgraded and sold to the grid at current feed-in tariff of $70 € / \mathrm{MWh}$. This has dramatic consequences for the revenue of the whole system, bringing it down to $16,780 € /$ year or a paltry $6 \%$ of the optimal revenue. For any feed-in tariff less than $90 \%$ of the current value, part of the biogas will be upgraded and fed in to the gas grid, with strong negative influence on the overall revenue. These scenarios make clear that any bio-based regional energy system is still critically dependent on the electricity market conditions for feed-in of renewable-based electricity.

Scenario group E was dedicated to investigate the impact of resource limitations. A limitation on wood does not have grave impacts on the economic performance of the system, eliminating the wood gasification, increasing the utilisation of grass resources to $81 \%$ and $76 \%$ for grassland and fields, respectively, and lowering the revenue to $92 \%$ of the optimal value. Restrictions on bio-waste however will have more severe results as the revenue will be decreased to $58 \%$ of the optimal value.

Reducing the potential of manure to $10 \%$ will result in a general reduction of the production of biogas and considerable economic impact, too. Revenue will fall to $73 \%$ of the optimum value.

The most sensitive resource here is grass. If no grass is available, the provision of energy again is reduced considerably and wood is utilised to a higher degree (but with $2.6 \%$ of the available potential still easily manageable). Revenue however will fall to $13 \%$ of the optimum value.

Finally, scenario group $\mathrm{F}$ investigated the influence of the price that might be achieved for the digestate (used as fertilizer). A price of $4 € / \mathrm{m}^{3}$ was assumed for the optimal technology network. If no price from this product can be achieved on the market, the revenue of the whole energy system is reduced to $55 \%$, a (very optimistic) doubling of the price to $8 € / \mathrm{m}^{3}$ will however increase the revenue to $228 \%$ of the optimum value.
Taken together, the scenarios indicate that anaerobic digestion, wood gasification and CHP units are stable choices for Thannhausen North and Thannhausen South, i.e. appear for most of the scenarios. Opposed to that, biogas plants and CHP units at Mortantsch appear less frequently than at the other two locations. Moreover, wood gasification at Mortantsch appears rarely.

The scenario calculations indicate no shortages in resources to provide energy to a relatively large industrial complex. Only municipal waste is utilised fully by almost all scenarios. The calculations show however that grass and manure are key resources in the supply line of any energy system on the base of renewable resources that may support industry in the region. This is justified by the fact that they comprise the biggest shares of the digesters' feedstock. It is therefore of critical importance to secure these resources in the long term.

For a better visual comparison, Figures 3 and 4 illustrate the results for these scenario groups and the optimal initial structure regarding the revenue and energy production, respectively. The scenario groups can be described as follows:

- A: There is little variation in the scenarios with lower demand of district heat, except 100\% district heat use brings high revenue, also due to increased electricity production.

- B: An exclusion of location 3 increases energy production of locations 1 and 2. In this regard, transport distances are decreased and revenue is even higher compared with scenarios of higher energy production using all three locations.

- C: A higher feed-in tariff for biogas directly leads to an upgrade of biogas instead of a reduction of heat production from biogas. A higher natural gas price creates slightly less revenue than a higher biogas feed-in tariff.

- D: When there are little or no electricity tariffs, the creation of revenue shifts to upgraded biogas and revenue decreases drastically.

- E: Grass is the key resource of the region strongly influencing the creation of revenue.

- F: When digestate is returned to the fields and the value of replacing common fertilisers can be recognised, a selling price for digestate can increase the revenue.

The actors in the region are driven by different interests. The industrial company ELIN Motorenwerk and the energy supplier Energie Steiermark have to reach a profitable operating range. The industry already covers its heat demand with a gas burner. Changing the burner to a renewable based burner could only be accepted by the company when they get cheaper energy prices or they 


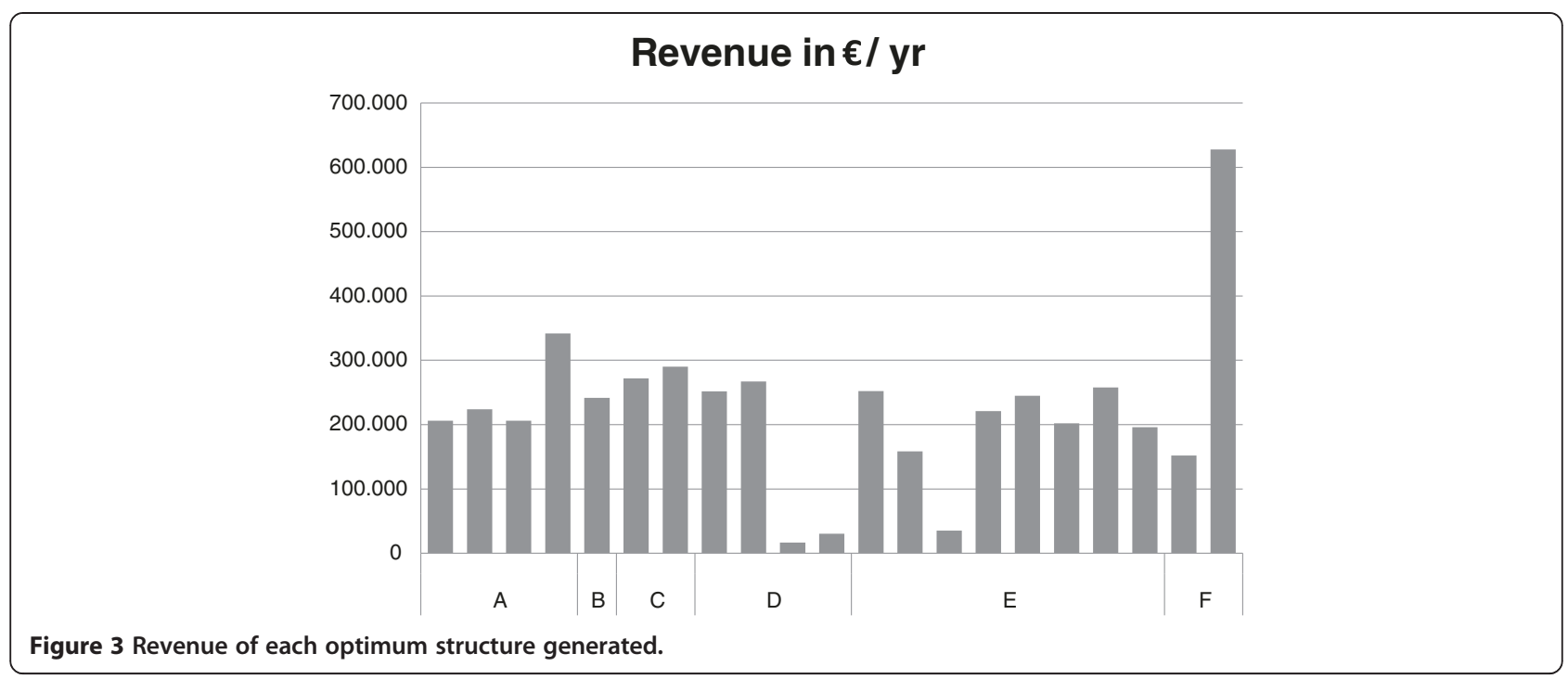

benefit from other advantages like external energy production and no additional costs. The interests of the energy region and the municipalities are not only a reduction of carbon emissions and employment creation in the region, but also hit a common point of interest with industry namely a reduction of dependencies from imported fossil fuels minimising economic uncertainties.

\section{Conclusions}

The energy technology network resulting from (economic) optimisation features a number of grid-overarching technologies that supply different distribution grids at the same time or may be used to switch between grids. Examples are CHP units that serve heat as well as electricity grids or biogas units that either serve CHP (in themselves already grid overarching) or may even serve gas grids when coupled with gas cleaning units. This grid-overarching nature of such regional energy systems will become even more important when considering the impact of other intermittent energy sources like wind power and photovoltaic, either within or outside the region in question: by smart operation of these technologies, the regional energy systems will contribute to the task of stabilising grids by switching between them to optimise energy storage capacities. In these cases, biogas continuously produced in a digester can be used to supply electricity via a CHP in times of low electricity supply or produce cleaned gas to inject in the gas grid in times of electricity peak production. $\mathrm{CHP}$ in turn can be operated following electricity demand and store the heat they produce as heat stored at much lower cost than electricity.

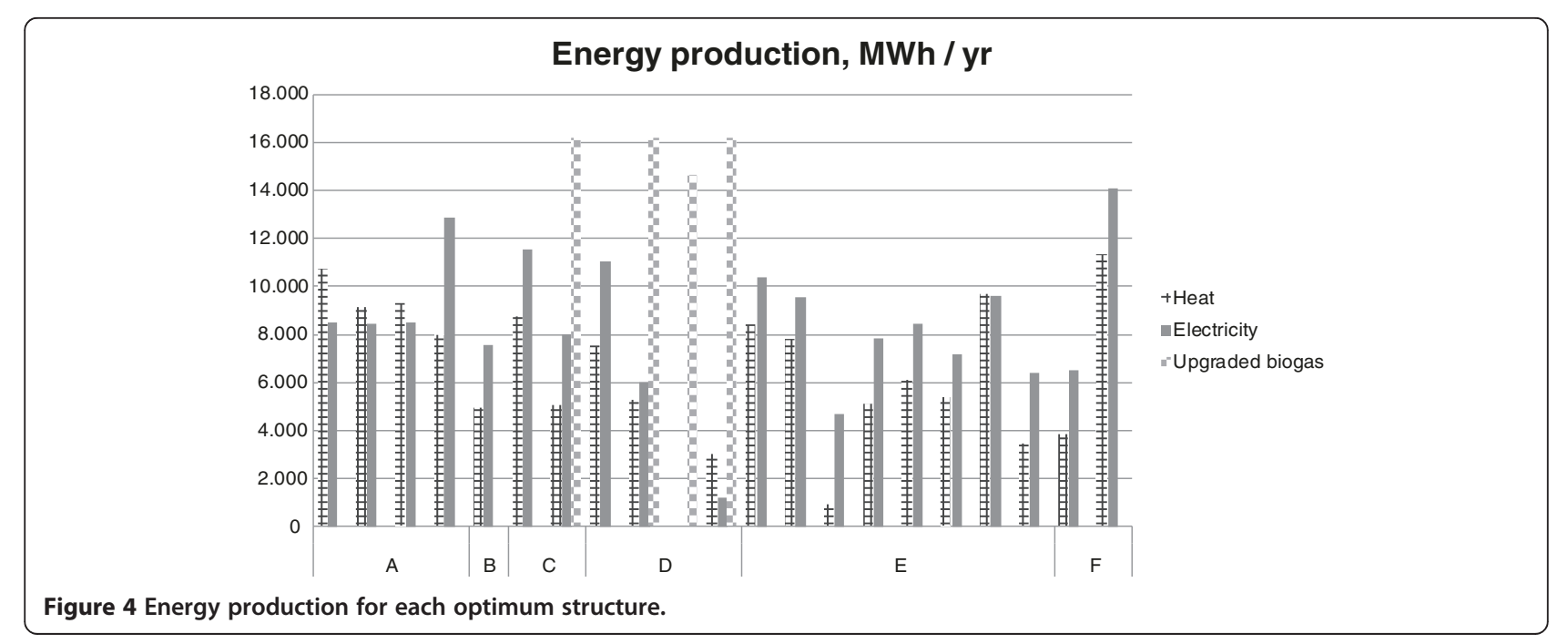


In methodological terms, the work presented here underscores the role and importance of reliable optimisation methods for whole technology networks. They allow comparing optimised structures (scenarios) resulting from different parametric frameworks (demand and supply variations, variations in prices and cost) as well as structural restrictions (e.g. site restrictions). Only if stakeholders are provided with optimised alternatives will they enter a meaningful discourse; as otherwise, uncertainty about the systemic impact of differing actor interests as well as projections of future trends will inevitably lead to planning gridlock and hamper consensual solutions necessary for deep restructuring of the energy system. The paper shows that a large industrial site in a region with limited bio-resources may be provided with energy from bio-resources. It shows however that a full-energy turn-around requires careful planning of resources and smart energy systems that link supply for industries and urban centres, utilising and possibly extending existing distribution grids.

The results represent an adaptable optimum technology network for the case study region fulfilling the main objective of the study. Hence, the generated scenarios identify requested price limits and stable technologies related to dependencies on existing technology network, available resources, prices, energy supply and demand situation of the region. The results presented here clearly show that optimal solutions by themselves are interesting but by no means sufficient for decision support. Only if thorough scenario evaluation is added to the optimisation, stakeholders will find a meaningful 'playing field' for their discourse. In the case of this work, the scenarios revealed some more general insights that might also be applicable to other regions where industrial sites shall be supported by regional resources.

One particularly interesting aspect here is that, already with current market situations, sustainable regional energy systems are very close to economic viability for supporting large consumers on a regional base. Another insight is that heat demand outside industry (e.g. for settlements) will critically influence the economic success for regional energy systems. Besides, results point out that electricity market regulation (e.g. feed-in tariffs) is still decisive for the chance to implement such systems. Another interesting aspect is that the availability of lowgrade resources (manure, bio-waste) will have particular impact on the revenue of such systems.

\section{Appendix}

Prices of resources, capacity of transportation, maximum capacity of technologies and input/output flows and scenario groups are presented in Tables 4, 5, 6 and 7 , respectively.
Table 4 Prices of resources

\begin{tabular}{|c|c|}
\hline Resource & Price \\
\hline \multicolumn{2}{|l|}{ Input (materials) ${ }^{a}$} \\
\hline Natural gas & $42.5 € / \mathrm{MWh}$ \\
\hline Diesel & $1,635 € / t$ \\
\hline Electricity & $150 € / \mathrm{MWh}$ \\
\hline Meadow grass (68\% water content) & $38 € / \mathrm{t}$ \\
\hline Grass (68\% water content) & $38 € / \mathrm{t}$ \\
\hline Miscanthus ( $14 \%$ water content) & $68.18 € / t$ \\
\hline Short rotation (60\% water content) & $31.35 € / t$ \\
\hline Short rotation (15\% water content) & $66.63 € / t$ \\
\hline Wood chips (50\% water content) & $35 € / t$ \\
\hline Wood chips (15\% water content) & $59.5 € / t$ \\
\hline Municipal waste ( $71.3 \%$ water content) & $7.4 € / t$ \\
\hline Manure (93.9\% water content) & $4 € / t$ \\
\hline \multicolumn{2}{|l|}{ Output (products) } \\
\hline Domestic heat & $35 € / \mathrm{MW}_{\text {th }}$ \\
\hline Industrial heat & $45 € / \mathrm{MW}_{\text {th }}$ \\
\hline Feed-in the grid biogas & $70 € / M W$ \\
\hline Feed-in tariff (biogas), up to $250 \mathrm{~kW}_{\mathrm{el}}$ & $195 € / \mathrm{MW}_{\mathrm{el}}$ \\
\hline Feed-in tariff (biogas), 250 to $500 \mathrm{~kW}_{\mathrm{el}}$ & $169.3 € / \mathrm{MW}_{\mathrm{el}}$ \\
\hline Feed-in tariff (biogas), 500 to $750 \mathrm{~kW}_{\mathrm{el}}$ & $133.4 € / \mathrm{MW}_{\mathrm{el}}$ \\
\hline Feed-in tariff (biogas), from $750 \mathrm{~kW}_{\mathrm{el}}$ & $129.3 € / \mathrm{MW}_{\mathrm{el}}$ \\
\hline Feed-in tariff (biomass), up to $2 \mathrm{MW}_{\mathrm{el}}$ & $120.3 € / \mathrm{MW}_{\mathrm{el}}$ \\
\hline Digestate & $4 € / m^{3}$ \\
\hline Remuneration tariff municipal waste & $70 € / \mathrm{t}$ \\
\hline
\end{tabular}

All costs are decided by regional actors. ${ }^{\mathrm{a} P r i c e}$ (materials); ${ }^{\mathrm{b}}$ Price (sale); $\mathrm{t}$, tons.

Table 5 Capacity of transportation

\begin{tabular}{|c|c|c|}
\hline Resources & Transportation type & Prices (transport) \\
\hline \multirow[t]{2}{*}{ Meadow grass/grass } & Fixed (40 t/ride) & $6.67 € /$ ride \\
\hline & Varying (40 t/ride) & $1.63 € / \mathrm{t} \cdot \mathrm{DM} \cdot \mathrm{km}$ \\
\hline $\begin{array}{l}\text { Miscanthus/Short rotation/ } \\
\text { Woodchips/Municipal }\end{array}$ & Fixed (40 t/ride) & $8.33 € /$ ride \\
\hline waste & Varying (40 t/ride) & $0.4 € / B T W \mathrm{~m}^{3} \cdot \mathrm{km}$ \\
\hline \multirow[t]{2}{*}{ Manure } & Fixed (27 t/ride) & $20 € /$ ride \\
\hline & Varying (27 t/ride) & $5 € / \mathrm{t} \mathrm{DM} \cdot \mathrm{km}$ \\
\hline
\end{tabular}

$\mathrm{t}$, tons; DM, dry mass; BTW $\mathrm{m}^{3}$, loose cubic metre. 
Table 6 Maximum capacity of technologies and input/output flows

\begin{tabular}{|c|c|c|c|}
\hline Technology & Capacity/Efficiency & Input & Output \\
\hline \multirow[t]{3}{*}{ Digester A } & CHP 80 to $160 \mathrm{~kW}_{\mathrm{el}}$ & - Electricity & - Biogas \\
\hline & $\eta_{\text {total }}=0.78$ to 0.81 & • Heat, NT & - Digestate \\
\hline & & - Manure & \\
\hline \multirow[t]{4}{*}{ Digester B } & CHP 80 to $250 \mathrm{~kW}_{\mathrm{el}}$ & - Electricity & - Biogas \\
\hline & $\eta_{\text {total }}=0.78$ to 81 & • Heat, NT & - Digestate \\
\hline & & - Manure & \\
\hline & & - Grass & \\
\hline \multirow[t]{5}{*}{ Digester C } & CHP 80 to $250 \mathrm{~kW}_{\mathrm{el}}$ & - Electricity & - Biogas \\
\hline & $\eta_{\text {total }}=0.78$ to 81 & • Heat, NT & - Digestate \\
\hline & & - Manure & \\
\hline & & - Grass & \\
\hline & & - Municip. waste & \\
\hline \multirow[t]{5}{*}{$\mathrm{CHP}$} & $80 \mathrm{~kW}_{\mathrm{el}}$ to $3 \mathrm{MW}_{\mathrm{el}}$ & - Electricity & • Heat, HT \\
\hline & $\eta_{\text {total }}=0.78$ to 0.85 & - Biogas & • Heat, NT \\
\hline & $\eta_{\mathrm{el}}=0.42$ & - Transformer cost & - Electricity \\
\hline & $\eta_{\mathrm{th}, H T}=0.18$ & & \\
\hline & $\eta_{\mathrm{th}, \mathrm{NT}}=0.25$ & & \\
\hline \multirow[t]{2}{*}{ Gas-fired boilers } & 290 to $1,500 \mathrm{~kW}_{\text {thr }}$ (natural gas/biogas) & - Electricity & • Heat \\
\hline & $\eta_{\text {th }}=0.8$ to 0.93 & - Natural gas/ Biogas & \\
\hline \multirow[t]{4}{*}{ Microgas turbines and small turbines } & 30 to $1,000 \mathrm{kWel}_{\mathrm{el}}$ & - Electricity & - Heat \\
\hline & $\eta_{\text {total }}=0.80$ to 0.87 & - Biogas & - Electricity \\
\hline & $\eta_{\mathrm{el}}=0.26$ to 0.33 & & \\
\hline & $\eta_{\mathrm{th}}=0.46$ to 0.61 & & \\
\hline \multirow[t]{2}{*}{ Wood gasifier } & $250 \mathrm{~kW}_{\mathrm{el}}$ & - Electricity & • Heat \\
\hline & $\eta_{\text {total }}=0.74$ & - Fuel LHV & - Electricity \\
\hline \multirow[t]{2}{*}{ PSA } & Methane content & - Electricity & - Upgraded biogas \\
\hline & in raw biogas: $55 \%$ & - Raw biogas & \\
\hline Raw biogas pipeline & var. & - Electricity & - Raw biogas \\
\hline \multirow[t]{2}{*}{ Biogas feed-in station } & var. & - Electricity & - Upgraded biogas \\
\hline & & - Upgraded biogas & \\
\hline District heating pipelines & var. & - Electricity & - Transported heat \\
\hline \multirow[t]{3}{*}{ Dryer } & 1.76 to $12.5 \mathrm{t} / \mathrm{h}$ & - Electricity & - Dryer output \\
\hline & & • Heat, LT & \\
\hline & & - Drier input & \\
\hline Filtering and shredding & var. & - Municipality waste & - Municipality waste treated \\
\hline \multirow[t]{2}{*}{ Chopper } & $245.7 \mathrm{t} / \mathrm{h}$ & • Diesel & - Miscanthus chips \\
\hline & & - Miscanthus & \\
\hline
\end{tabular}


Table 7 Scenario groups

\begin{tabular}{ll}
\hline & Scenario and specific numbers \\
\hline A. DH demand limitation & 4 Scenarios \\
& Nos. A1 to A4 \\
B. Exclusion of Location 3 & 1 Scenario \\
& No. B1 \\
C. Sensitivity analysis of gas prices & 2 Scenarios \\
& Nos. C1 to C2 \\
E. Resources limitation & 8 Scenarios \\
& Nos. E12 to E19 \\
F. Digestate price variation & 2 Scenarios \\
& Nos. F1 to F2 \\
\hline
\end{tabular}

$\mathrm{DH}$, district heat.

\section{Abbreviations}

AD: anaerobic digestion-biogas plant; BG: biomass (wood) gasification; BTW $\mathrm{m}^{3}$ : loose cubic metre; CHP: combined heat and power; DM: dry mass; $\mathrm{DH}$ : district heat; $\mathrm{HT}$ : high temperature; $\mathrm{kW}_{\mathrm{el}}$ : kilowatt electric; $\mathrm{kWh}$ : kilowatt hour; $\mathrm{kWh}_{\mathrm{e}}$ : kilowatt hour electric; $\mathrm{kWh}_{\mathrm{th}}$ : kilowatt hour thermal; $\mathrm{LT}$ : low temperature; MWh: megawatt hour; $\mathrm{MWh}_{\mathrm{e}}$ : megawatt hour electric $M W h_{\text {th }}$ : megawatt hour thermal; PNS: process network synthesis; PSA: pressure swing adsorption-biogas cleaning; rm: residual moisture; t: tons; w: water content; $\eta_{\text {total: }}$ total efficiency; $\eta_{e}$ : electrical efficiency; $\eta_{\mathrm{th}}$ : thermal efficiency.

\section{Competing interests}

The authors declare that they have no competing interests.

\section{Authors' contributions}

SM and AG jointly elaborated the content of the article by collecting data, generating possible technology structures, making scenarios and doing feedback circles with regional actors for a realistic representation and fine tuning of the work to provide meaningful results. Both authors read and approved the final manuscript.

\section{Authors' information}

SM, born in 1983 in St. Andrä, Austria graduated in Environmental System Sciences from the University of Graz. He is currently working at the Institute for Process and Particle Engineering, Graz University of Technology. His research is focused on energy technology system optimisation in regions and rural and urban areas, holistic urban energy system planning and ecological evaluation. AG, born in 1987 in Thessaloniki, Greece. In 2011, she successfully completed her Chemical Engineering studies at Aristotle University of Thessaloniki, and in 2013, she graduated from the MSc program in Industrial Ecology from the University of Graz. AG contributed to this paper as part of her master thesis.

\section{Acknowledgements}

The research presented here was made during the iENERGY Weiz-Gleisdorf 2.0. The authors would like to thank for the funding by smart energy fit 4se Klima-und Energiefonds, built on the energy vision 2050, Smart Urban Region. The authors would also like to thank Christian Orthofer and Jörg Pfeifer from Energie Steiermark, Franz Kern von W.E.I.Z. (Weizer Energie-Innovations-Zentrum) and the management of the Energieregion Weiz-Gleisdorf for their profound support.

Received: 4 December 2013 Accepted: 5 March 2014 Published: 25 April 2014

\section{References}

1. Müller MO, Stämpfli A, Dold U, Hammer T (2011) Energy autarky, a conceptual framework for sustainable regional development. Energy Pol (39):5800-5810, doi.org/10.1016/j.enpol.2011.04.019
2. Schmidt J, Schoenhart M, Biberacher M, Guggenberger T, Hausl S, Kalt G, Leduc S, Schardinger I, Schmid E (2012) Regional energy autarky, potentials, costs and consequences for an Austrian region. Energy Pol 211(47):211-221, doi.org/10.1016/j.enpol.2012.04.059

3. Stoeglehner G, Niemetz N, Kettl KH (2012) Spatial dimensions of sustainable energy systems: new visions for integrated spatial and energy planning. Energy Sustainability Soc 1:2, Doi: 10.1186/2192-0567-1-2

4. Heinbach K, Aretz A, Hirschl B, Prahl A, Salecki S (2014) Renewable energies and their impact on local value added and employment. Energy Sustainability Soc 4:1, doi:10.1186/2192-0567-4-1

5. Lam HL, Varbanov P, Klemeš J (2011) Regional renewable energy and resource planning. Appl Energy (88/2):545-550, doi.org/10.1016/j. apenergy.2010.05.019

6. Nemet A, Klemeš JJ, Varbanov PS, Kravanja Z (2012) Methodology for maximising the use of renewables with variable availability. Energy (44/1):29-37, doi.org/10.1016/j.energy.2011.12.036

7. Vance L, Cabezas H, Heckl I, Bertok B, Friedler F (2013) Synthesis of sustainable energy supply chain by the P-graph framework. Ind Eng Chem Res 52(1):266-274

8. Friedler F, Varga JB, Fan LT (1995) Decision-mapping: a tool for consistent and complete decisions in process synthesis. Chem Eng Sci (50):1755-1768, doi.org/10.1016/0009-2509(95)00034-3

9. Friedler F, Tarjan K, Huang YW, Fan LT, Varga JB, Feher E (2011) P-graph: p-graph.com/pnsstudio, PNS Software Version 3.0.4. www.p-graph.com, last accessed on 12/02/2014

10. Narodoslawsky M, Niederl A, Halasz L (2008) Utilising renewable resources economically: new challenges and chances for process development. J Clean Prod (16/2):164-170, doi.org/10.1016/j.jclepro.2006.08.023

11. Niemetz N, Kettl KH, Eder M, Narodoslawsky M (2012) RegiOpt conceptual planner - identifying possible energy network solutions for regions. In: Sabev Varbanov P, Lam HL, Klemeš JJ (eds) Chemical Engineering Transactions, 29th edn., aidic.it/cet/12/29/087.pdf

doi:10.1186/2192-0567-4-9

Cite this article as: Maier and Gemenetzi: Optimal renewable energy systems for industries in rural regions. Energy, Sustainability and Society 2014 4:9.

\section{Submit your manuscript to a SpringerOpen ${ }^{\circ}$ journal and benefit from:}

- Convenient online submission

- Rigorous peer review

- Immediate publication on acceptance

- Open access: articles freely available online

- High visibility within the field

- Retaining the copyright to your article

Submit your next manuscript at $>$ springeropen.com 